\title{
The evaluation of the relevance of teaching of homeopathy at the medical school
}

\section{Francisco José de Freitas, Débora Alves dos Santos Fernandes}

Federal University of the State of Rio de Janeiro - UNIRIO, Rio de Janeiro, Brazil

\begin{abstract}
Background: In 1912 the Hahnemann Medical Faculty to graduate homeopathic physicians was created. This was one of the courses that originated the present Federal University of the State of Rio de Janeiro UNIRIO. Homeopathy in UNIRIO was consolidated during the 80s and 90 s through the relationship with other specialties. In 1999, the interface of Homeopathy and the curriculum guidelines of the Brazilian Ministry of Education justified the inclusion of Homeopathy as a compulsory subject in the medical course at UNIRIO. In 2001 a University program to improve the development of research called "Homeopathy - Health and Quality of Life", was created to integrate the activities of Teaching, Research and Extension.
\end{abstract}

Aim: To evaluate the relevance of the compulsory teaching of Homeopathy in the medical area at the Federal University of the State of Rio de Janeiro - UNIRIO, Brazil.

Methods: A prospective longitudinal qualitative and quantitative research was used with semi-structured questionnaires with open and closed questions at the beginning and end of each semester. Undergraduate students from the third year of the UNIRIO Medical Faculty (2008/March till 2009/September) who accepted the "Consent Form", were included. Students who didn't respond adequately to the questions were excluded. This research was approved and registered at the Brazilian Research Ethics Center. Microsoft Office Excel 2007 used to data collection and analysis.

Results: Total number of students attending the course during the four semesters: $304.70 \%$ answered the questionnaires. $60 \%$ of the students had heard of homeopathy before attending the homeopathy course (67\% as patients, $21 \%$ as patients and through media, $6 \%$ through media and $6 \%$ by other means of contact). $86 \%$ consider that homeopathy brought new knowledge to the medical and academic training. $72 \%$ consider that this knowledge could be applicable to their future career.

Conclusion: Most students aim to learn the guiding principles of homeopathy. Their aim is to know all available treatment, modalities and alternatives to allopathy in medical education. They considered that the learning of Homeopathy is a part of general medical training due to the fact that it has been a recognized medical specialty in Brazil since 1980. The student's opportunity to learn homeopathy during the undergraduate course in medical schools widens the individuality concept, "the doctor-patient relationship and the holistic vision of the patient". These results demonstrate the relevance of teaching homeopathy in the medical curriculum and the need to spread the teaching of homeopathy as a compulsory course for all other medical universities.

Keywords: teaching; medical universities. 
Conselho Nacional de Educação/Câmara de Educação Superior. Diretrizes Curriculares Nacionais. 2001.

Teixeira MZ. Homeopatia; desinformação e preconceito no ensino médico. Rev Bras Educ Med. 2007; 31 (1).

Teixeira MZ, et all. Homeopathy and acupuncture teaching at Faculdade de Medicina da USP: the undergraduates attitudes. São Paulo Med J. 2005; 123 (2).

\section{Avaliação da relevância do ensino da homeopatia na Faculdade de Medicina}

\section{RESUMO}

Introdução: A experiência da Homeopatia no curso de medicina da Universidade Federal do Rio de Janeiro Estado - UNIRIO, começou em 1912, com a criação da Faculdade de Medicina Hahnemanniana para formar médicos homeopatas. A Homeopatia na UNIRIO foi consolidada durante os anos 80 e 90, através do relacionamento com outras especialidades. Em 1999, o ensino da homeopatia passou a ser obrigatório durante a Reforma Curricular do Curso de Graduação na Área de Medicina da UNIRIO. A capacidade de associar a compreensão holística do paciente e da excelência da relação médico-paciente justifica essa inclusão, que foi de primordial importância para a formação e prática de médicos, de acordo com as diretrizes curriculares do Ministério da Educação. Com essa evolução, tornou-se necessário integrar as atividades de Ensino, Pesquisa e Extensão, através da "Homeopatia: Saúde e Qualidade de Vida" Programa de Universidade, criada em 2001. O Programa facilitou o desenvolvimento de pesquisas como esta.

Objetivos: Avaliar a relevância do ensino obrigatório da Homeopatia na área de medicina na Universidade Federal do Rio de Janeiro Estado - UNIRIO, Brasil.

Métodos: Pesquisa longitudinal prospectiva qualitativa e quantitativa, aprovada e registrada no Comitê de Ética em Pesquisa Brasileiro. Incluídos: estudantes do terceiro ano do curso de graduação em medicina da UNIRIO (de março de 2008 até setembro de 2009) que aceitaram o Termo de Consentimento Livre e Esclarecido. Os alunos que não responderam adequadamente às questões foram excluídos. Foi utilizado questionário semi-estruturado com perguntas abertas e fechadas, no início e no final do semestre. Foi utilizado Microsoft Office Excel 2007 para a coleta de dados e análise.

Metodologia: Total de alunos ao longo de quatro semestres: 304. 70\% responderam os questionários, sendo que $60 \%$ conheciam a homeopatia antes de assistir o curso homeopatia ( $67 \%$ como paciente, $21 \%$ dos pacientes e pela mídia, pelos meios de comunicação $6 \%$ e $6 \%$ por outros meios de contato), $86 \%$ consideram que a homeopatia trouxe novos conhecimento visando a formação médica e acadêmica, $72 \%$ consideram que esse conhecimento será aplicável à sua carreira futura.

Conclusão: A maioria dos estudantes objetiva aprender os princípios fundamentais da prática homeopática. Têm como objectivo conhecer todas as modalidades de tratamento disponíveis e alternativas para a alopatia na educação médica. Eles consideraram que a aprendizagem da homeopatia é uma parte da formação médica em geral, devido ao fato de que ser uma especialidade médica reconhecida no Brasil desde 1980. Oportunidade do aluno para aprender a homeopatia durante o curso de graduação em escolas médicas amplia o conceito de 
individualidade, a relação médico-paciente e visão holística do paciente. Estes resultados demonstram a relevância do ensino da homeopatia no currículo médico e da necessidade de difundir o ensino da homeopatia como um curso obrigatório para todas as outras universidades de medicina.

Palavras-chave: ensino da Homeopatia; universidades médicas.

\section{(c)) BY-NC-ND Licensed to GIRI}

Support: authors declare that this study received no funding

Conflict of interest: authors declare there is no conflict of interest

Correspondence author: Francisco José de Freitas - fjdefreitas@gmail.com , Débora Alves dos Santos Fernandes deboraunirio@yahoo.com.br

How to cite this article: Freitas FJ, Fernandes DAS. The Evaluation of the Relevance of Teaching of Homeopathy at the Medical School. Int J High Dilution Res [online]. 2011 [cited YYYY Month dd]; 10(36): 286-288. Proceedings of the XXV

GIRI Symposium and VIII CBFH; 2011 Sep 04-07; Foz do Iguaçu (Brazil). GIRI and ABFH; 2011; Available from: http://www.feg.unesp.br/ ojs/index.php/ijhdr/article/view/488/501 